\title{
Effect of Corporate Governance Mechanisms on Financial Performance of Insurance Companies in Nigeria
}

\author{
Ibe Happy Chukwudike Azutoru, ${ }^{1, *}$, Ugwuanyi Georgina Obinne ${ }^{1}$, Okanya Ogochukwu Chinelo ${ }^{2}$ \\ ${ }^{1}$ Department of Banking and Finance, Michael Okpara University of Agriculture, Umudike \\ ${ }^{2}$ Institute of Management \& Technology, Enugu \\ *Corresponding author: ibehappycsa@gmail.com
}

\begin{abstract}
This study investigated the effect of corporate governance on financial performance of Insurance companies in Nigeria. The study adopted ex-post facto research design and panel data covering five year period from 2011-2015 for twenty insurance companies. The study examined a range of corporate governance mechanisms such as board size, board independence, executive directors' remuneration, non-executive directors' remuneration, directors' ownership, institutional ownership, foreign ownership and the study controlled the effect of the firm size using log of total assets. The Fixed effects model was used to evaluate the effect of these corporate governance mechanisms on financial performance of Nigerian insurance companies. The fixed effect econometric estimates showed that, board size and non-executive directors' remuneration have negative and significant effect on financial performance proxy by return on assets (ROA). While board independence, and institutional ownership indicated positive and significant impact on the financial performance as predicted by agency theory. However, contrary to theoretical predictions executive directors' remuneration, directors' ownership, and foreign ownership did not make significant impact on the financial performance of Nigerian insurance companies. However, the fixed effect econometric estimator employed in this study indicated that corporate governance mechanisms affects the financial performance of Insurance companies in Nigeria. Therefore, the study recommends among other things that the board be restructured to a manageable size, and suggested that a performance-based remuneration be design for the directors. In addition, more non-executive directors should be appointed to the corporate board to enhance the effectiveness of the board in aligning the interest of the stakeholders.
\end{abstract}

Keywords: corporate governance, board size, board independence, directors' remuneration, directors' ownership, institutional ownership, foreign ownership, financial performance

Cite This Article: Ibe Happy Chukwudike Azutoru, Ugwuanyi Georgina Obinne, and Okanya, Ogochukwu Chinelo, "Effect of Corporate Governance Mechanisms on Financial Performance of Insurance Companies in Nigeria.” Journal of Finance and Accounting, vol. 5, no. 3 (2017): 93-103. doi: 10.12691/jfa-5-3-4.

\section{Introduction}

In recent times, various modes of enhancing corporate governance have been at the forefront of international debate $[1,2]$. These modes of enhancement, which has become a public and academic subject of discussion, focuses on board characteristics (Board Size, Board Independence, Board diversity), board committees (audit committee, remuneration committee, risk management committee), remuneration of directors, and ownership structures of businesses [3,4,5].

This unprecedented interest in corporate governance mechanisms and standards inevitably started because of corporate failures around the world, and specifically partly because of the six (6) key findings of the United State Senate Permanent Investigation Subcommittee on the role of Enron board of directors in Enron's collapse and other cases [6,7]. The highlighted reasons for Enron's collapse include inappropriate conflict of interest, excessive remuneration of company executives and lack of board independence [8]. This has been referred as a historic period of corporate greed, unprecedented fraud, widespread "gatekeeper" failure, and organizational misgovernance [9]. This onslaught of corporate scandals has forced the World to recognize and acknowledge the place of corporate governance practices on the global economy $[7,10,11]$.

Following the revelation of the fraudulent actions and self-servicing behaviour of managers at the expense of shareholders, caused by the separation of the principals from management; owing to wide spread ownership of the business, stakeholders in corporate business have now taken corporate governance serious $[9,12,13]$. Developing economies (such as Nigeria) have come to recognize the need for sound corporate governance, as international investors and many domestic investors are hesitant to invest in companies which do not subscribe to good corporate governance principles [14].

Studies have been carried out on the effect of corporate governance mechanisms on firms' performance in Nigeria 
[15-21]. However, there is scanty or no empirical literature on corporate governance addressing the combined effect of board characteristics, directors' remuneration, and ownership structure on financial performance of Insurance Companies in Nigeria. Almost all prior literatures in Nigeria focused on individual effect of either board characteristics, directors' remuneration or ownership structure on firms' financial performance. Thus, it is still unclear if good governance is an additional burden or benefit to corporations. Very few studies, investigate the combined effect of board characteristics and ownership structure [9,22]. These reflect the lack of extensive research on the subject matter. Consequently, there is a great motivation to discover the unbiased impact of corporate governance by investigating the combined effect of more corporate governance mechanisms (board characteristics, directors' remuneration, and ownership structure) on financial performance of insurance companies in Nigeria.

\subsection{Objectives of The Study}

The broad objective of this study is to analyse the effect of corporate governance on financial performance of insurance companies in Nigeria.

Specifically, the objectives of this study are:

i. To ascertain the impact of board size on return on assets of Insurance companies in Nigeria.

ii. To estimate the effect of board independence on return on assets of insurance companies in Nigeria.

iii. To assess the influence of executive directors' remuneration on return on assets of insurance companies in Nigeria.

iv. To evaluate the impact of non-executive directors' remuneration on the return on assets of insurance companies in Nigeria.

v. To determine the effect of directors' ownership on return on assets of insurance companies in Nigeria.

vi. To assess the influence of institutional ownership on return on assets of insurance companies in Nigeria.

vii. To ascertain the impact of foreign ownership on return on assets of insurance companies in Nigeria.

\subsection{Research Hypotheses}

Corporate governance has no significant impact on financial performance of insurance companies in Nigeria, is the main hypothesis tested.
Specifically, the following hypotheses are tested:

$\boldsymbol{H}_{\mathbf{0}}$ 1: Board size has no significant impact on the return on assets of insurance companies in Nigeria.

$\boldsymbol{H}_{\mathbf{0}}$ 2: Board independence has no significant effect on the return on assets of insurance companies in Nigeria.

$\boldsymbol{H}_{\mathbf{0}}$ 3: Executive directors' remuneration has no significant influence on the return on assets of insurance companies in Nigeria.

$\boldsymbol{H}_{\mathbf{0}}$ 4: Non-executive directors' remuneration has no significant impact on the return on assets of insurance companies in Nigeria.

$\boldsymbol{H}_{\mathbf{0}}$ 5: Directors' ownership does not significantly affect the return on assets of insurance companies in Nigeria.

$\boldsymbol{H}_{\mathbf{0}}$ 6: Institutional ownership does not significantly affect the return on assets of insurance companies in Nigeria.

$\boldsymbol{H}_{\mathbf{0}}$ 7: Foreign ownership does not significantly affect the return on assets of insurance companies in Nigeria.

\section{Literature Review}

\subsection{Conceptual Framework}

\subsubsection{Concept of Corporate Governance}

Though, due to changes and perpetually expanding boundaries corporate governance cannot be comprehensive define [23]. The definitions varies according to the context, cultural situations and perspectives of researchers and policy makers [24]. However, corporate governance involves maintaining good relationships between management, boards, shareholders and other stakeholders such as employees and the community [25,26].

In Nigeria, the insurance companies governance is guided by the National Insurance Commission (NAICOM) code 2009 directed at all insurance, reinsurance, broking, and loss adjusting companies in Nigeria. And the Security and Exchange Commission (SEC) code of corporate governance 2003 addressed to public companies listed in Nigeria Stock Exchange (NSE). In the year 2011, the SEC code was reviewed to enhance corporate governance effectiveness.

\subsubsection{Corporate Governance Mechanisms}

Some of the mechanisms of corporate governance of interest to this study are highlighted below.

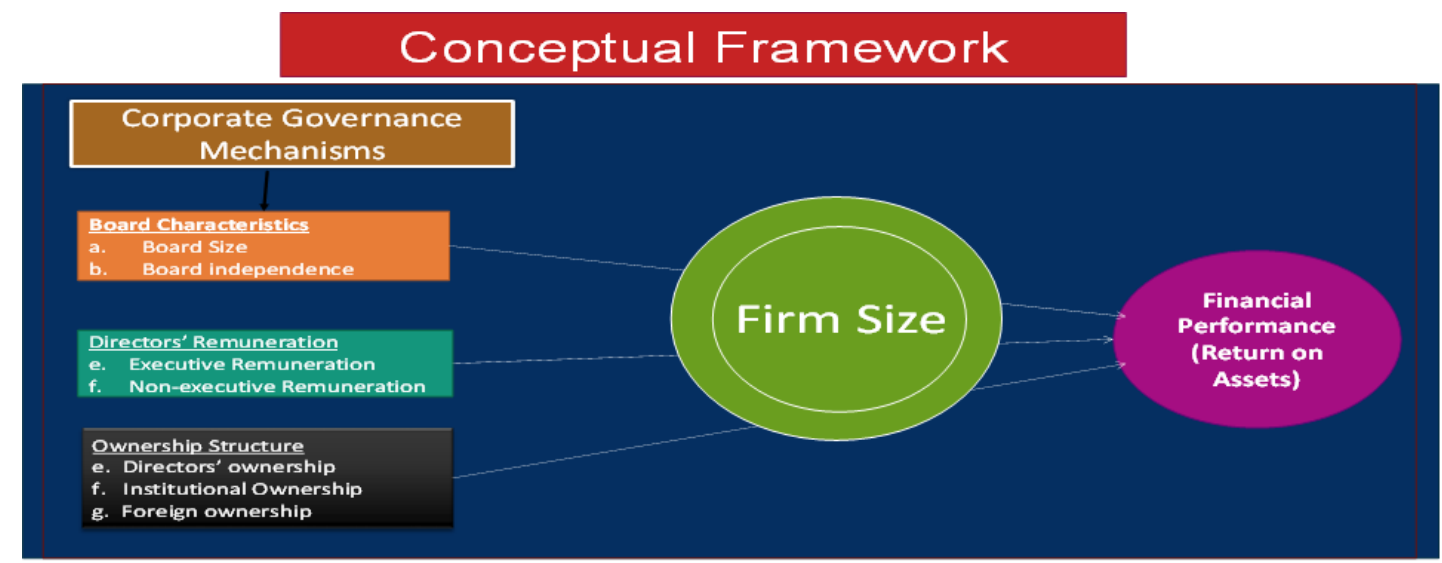

Figure 1. Conceptual framework of corporate governance and firms’ performance 


\section{Board size}

Board size refers to the total number of directors on the board of any corporate organization. Establishing the ideal board size for organizations is very important because the number and quality of directors in a firm determines and influences the board functioning and hence corporate performance $[7,15,27,28]$. However, the issue of what size constitute the ideal board size is still being debated among scholars till date.

Some scholars have argued in favour of smaller boards [27,28,29,30,31,32]. Lipton and Lorsch [28] in their argument for small board size, argued that larger groups face problems of social loafing and free riding. As board increase in size, free riding increases and reduces the efficiency of the board.

Scholars supported large boards on the ground that they would provide greater monitoring and advice $[33,34,35,36,37,38]$.

The NAICOM code 2009, provide that not less than seven and not more than fifteen directors shall be in the board of insurance, reinsurance and loss adjusting companies.

\section{Board independence}

A board comprising a reasonable proportion of non-executive directors is more likely to be independent of management than one dominated by executive directors, and therefore more likely to protect the interests of other stakeholders [2,7,39]. Board independence in this study represents the proportion of non-executive directors on the board.

On the issue of how many non-executive directors a board should have, a review of the NAICOM code 2009, mandate that executive directors on the board shall not exceed $40 \%$ of the board membership.

\section{Directors' remuneration}

Directors' remuneration is the payment made for services or employment of directors on the board of company or corporation [40]. This includes the basic salary and other monetary or non-monetary benefits that an executive and directors' fees, and sitting allowance pay to the non-executive directors in a financial year. Directors' remuneration is consistently and narrowly connected with the issue of corporate governance $[41,42,43]$. The agency theory and empirical studies suggests that good remuneration pack for executive and non-executive directors can help to reduce the opportunistic behaviour of managers [39,44,45].

It's important to note that the NAICOM code did not specify what the make-up of remuneration package for executive and non-executive directors should be.

\section{Ownership structure}

Corporate governance literatures on ownership structure pays much attention to the issue of shareholders identity $[46,47]$. The argument being that the functional objective and cost of monitoring managers vary significantly for different types of owners [48].

Scholars have argued that the ownership structure is an important factor that affects a firm's performance $[49,50]$.
In this study, directors' ownership, institutional ownership, and foreign ownership on performance was investigated.

\section{Directors' ownership}

Scholars have argue that directors with direct or indirect ownership in a firm under their watch, will perform their monitoring and strategic responsibilities effective [51-57].

\section{Institutional ownership}

Agency theory and empirical studies indicate that large shareholders might have greater incentive to monitor managers, while institutions might have the opportunity, resources, and ability to monitor and discipline managers. [58,59,60,61]. Alfaraih et al. [62], Shleifer and Vishny, [50], and Xu and Wang [47] found a positive relationship between firms' value and institutional ownership.

\section{Foreign ownership}

Foreign ownership embraces all forms of foreign private investment which confers control and ownership over a package of assets in a foreign country [63]. The package consists of financial capital, expertise (management, financial and marketing skills), technology, etc. The benefits accruing from such participation vary according to the extent of economic development of the host nation.

\section{Financial performance}

To survive and grow over a long period, companies need to earn profit in their operations. According to Kajola [15], firm performance is an essential concept that connote the manner in which financial resources of a firm are prudently used to achieve its overall objective. Pandey [64], stated that sufficient profit must be earned, to sustain the operation of the business, to be able to obtain fund from investors for expansion and growth, and to contribute towards the social overheads for the welfare of the society. This study used return on assets (ROA) as firms' financial performance measurement.

The return on assets ratio, often called the return on total assets, is a profitability ratio that measures the net income produced by total assets during a period by comparing net income to the total assets. ROA gives an idea as to how efficient management is at using its assets to generate earnings [64].

\subsection{Theoretical Framework}

In general, there is no agreed theoretical explanation among theorists and academics with regard to these relationships. A review of the literature shows that five main theoretical frameworks have been used to explain and analyse the correlations between these elements and these have been the subject of earlier empirical studies; namely, agency theory, steward theory, and stakeholders' theory. Although these set of theories is not comprehensive, they are prominent and well-known in their respective fields [7].

\subsection{Empirical Review}

Empirically, Yermack [30] studied higher market valuation of companies with a small board of directors in 
United States. A sample size of 452 large U.S industrial corporations between 1984 and 1991 was used. The study used correlation and regression analysis to estimate the relationship between board size and performance of firms, using Tobin's $\mathrm{Q}$ as proxy for performance. The result shows a negative correlation between board size and profitability. More so, Vincent and Nicole [65] examine the relationship between firm performance and board characteristics in Ireland. Sample size of 77 firms listed on Irish Stock Exchange at the end of December 2001. The results show that board size exhibits a significant negative association with firm performance, and a positive and significant association between firm performance and the percentage of non-executives on the board. Eisenberg, Sundgren and Wells [31] studied larger board size and decreasing firm value in small. The study examined the relationship between board size and financial performance, using Sample size of 838 firms. The study indicate a significant negative correlation between board size and profitability. Kajola [15] examine the relationship between four corporate governance mechanisms (board size, board composition, chief executive status, and audit committee) and two firm performance measures (return on equity, ROE, and profit margin, PM) in Nigerian companies. The results provide evidence of a positive significant relationship between ROE and board size. However, the study found no relationship between the proportion of non-executive directors and firm performance. Sanda, Mikailu and Garba [22] examine the relationship between corporate governance mechanisms and firm financial performance in Nigeria. Sample of 93 firms listed on the Nigeria Stock Exchange. The result shows that board size has no significant relationship with firm performance. In the same way Masood [66], found no significant relationship between board size and firm performance (using return on equity and return on assets).

Uadiale [67] examines the impact of board structure on corporate financial performance in Nigeria. The study found the existence of strong positive association between board size and corporate financial performance. However, a negative association was observed between directors' stockholding and firm financial performance measures. In addition, the study reveals a negative association between return on capital employed (ROE) and CEO duality, while a strong positive association was observed between ROE and CEO duality. The study suggests that large board size should be encouraged and the composition of outside directors as members of the board should be sustained and improved upon to enhance corporate financial performance.

Amran [68] empirically studied the association between Corporate Governance Mechanisms and Company Performances. The study revealed that director's qualification helps to enhance the performance of non-family controlled firms but insignificant for family controlled firms. Board size and leadership duality was a significant negative influence on family controlled firms performance but insignificant for non-family controlled firms. Firm age was a significant negative and positive association between the performance of family controlled and non-family controlled firms respectively. On the other hand, there was a significant negative relationship between firm size and performance of both family controlled and non-family controlled firms. The other variables such as board independence and director's professional qualification were insignificant for both classes of firms.

Al-Manaseer, Al-Hindawi, Al-Dahiyat and Sartawi [69] empirically investigated the impact of corporate governance on performance using 15 Jordanian banks listed at Amman Stock Exchange from the year 2007 to 2009 with a total of 45 bank-year observation. The study revealed a significant negative relation between board size and banks performance as measured by return on equity and earnings per share but insignificant negative association of board size with return on asset and profit margin was found. Bank size was negatively related with return on asset, return on equity and profit margin but only significant with profit margin. The study also reveals a positive association between board composition and foreign ownership and bank performance. In addition, chief executive officer status has a negative influence. Finally, the researchers suggest extending the study period.

Some empirical evidence suggests that non-executive directors can improve board effectiveness and firm performance. For instance, some studies [37,65,70,71] found a positive and significant relationship between the proportion of non-executive directors and firm performance. However, other studies [72,73] found a negatively significant relationship between the proportion of non-executive directors and firm performance, and some studies [15,74,75] found no relationship between the proportion of non-executive directors and firm performance. Moreover, [22,76] found no evidence of a significant relationship between the proportion of non-executive directors and firm performance.

Miyienda et al [43] investigated the relationship between directors' remuneration and firms' performance in Nairobi. The study found a positive relationship between directors' remuneration and ROE, EAT and Tobin's Q. While the positive relationship between directors' remuneration and EAT is strong, the relationship between director's remuneration and ROE and Tobin's Q are weak. Junaidu and Sani [21] studied the effect of top executive compensation on the financial performance of Nigerian banks. The study found a positive and significant link between executive compensation and profit before tax. Hristos et al [77], examined the relationship between directors' remuneration and firm performance in Australian banking, and found no relationship between directors' remuneration and firm performance. However, the study reveals a strong positive relationship between CEO remuneration and prior year bank performance. Jegede [18] investigated the effect of Executive compensation structure and ownership on firms' performance with a random sample of 240 personnel from cross-section of banks in Lagos State, Nigeria. The result shows that Executive compensation structures do not affect banks' market value.

Ani, Ilo, Timothy, and Eneje [78], investigated the impact of directors' equity ownership on bank profitability in Nigeria. The study found a negative relationship between directors' ownership and bank profitability. However, the relationship is not statistically significant. Gugong et al, [79] examined the impact of ownership structure on the financial performance of listed insurance firms in Nigeria. The study uses panel data for seventeen 
(17) firms for the period 2001 - 2010 (10 years). The finding indicates that there is a positive significant relationship between institutional ownership and firm's performance as measured by ROA and ROE. It equally found a significant relationship between managerial ownership and firm performance. Tsegba and Herbert [80] examined relationship between two patterns of ownership structure (concentrated and Foreign) and their impact on firms performance in Nigeria. The study covered a sample of 72 non-financial firms listed on the Nigerian stock exchange for five years period (2003-2007). The empirical result indicates that foreign ownership has significant positive impact on firms' performance. The study equally disclosed no evidence of association between ownership concentration and firms' performance.

Uwuigbe and Olusanmi [81], examined the relationship between ownership structure and the financial performance of listed firms in the financial sector of the Nigerian economy. A total of 31 selected listed firms in the Nigerian stock exchange market were studied from 2006 to 2010. The study concluded that board ownership has a significant and positive relationship with return on assets. Secondly, the study found a positive and significant relationship between institutional ownership and return on assets. Lastly, the study equally found a positive and significant relationship between foreign ownership and return on assets in Nigeria.

Mihai and Mihai [82] investigated the impact of foreign ownership on the performance of Romanian listed manufacturing companies. The study concluded that there is a non-significant link between economic and financial performance and the existence of foreign ownership. Houda, Mohammed and Mohammad [48] examine the effect of ownership structure and board characteristic on bank performance of GCC counties. Evidence indicates that the extent of the foreign ownership level has significant positive association with the bank performance. Concentrated ownership have a significant negative impact on bank performance. The study equally found that institutional ownership does not have any significant effect on the performance of bank. Leung and Horwitz [83] in their study of corporate governance and firm value during a financial crisis. The study covered 506 non-financial firms listed on the Hong Kong Stock exchange from 1997 to 1998 . The study concluded that there is a positive relationship between directors' ownership and firm performance. Bhagat and Bolton [84] examined corporate governance and firm performance of 1500 large firms from 1999 to 2007. The result indicates that directors' ownership as a proxy for corporate governance is positively related to firm performance. Millet-Reyes and Zhao [85] studied 665 non-financial firms from 2000 to 2004. The study covered 174 French companies from 28 sectors. The study used multiple regression analysis method. The study concluded that there is no significant relationship between foreign ownership and firm performance.

\section{Methodology}

Ex-post facto research design also known as causal comparative research design was adopted to examine the effect of corporate governance mechanisms on financial performance of Insurance companies in Nigeria. In order to collect appropriate, reliable and valid data, considering the research design, nature of the study and based on related literature, secondary data formed the database. The secondary data were collected from various annual reports of the sampled Insurance companies in Nigeria.

The population of this study includes the thirty one (31) insurance companies licensed and quoted on the Nigerian stock exchange market as at 2015 (NAICOM, 2015; SEC, 2015). While the sample size of twenty (20) companies were selected by Purposive sampling Technique.

\subsection{Model Specification}

The regression models used in analysing the data and assessing the impact of corporate governance mechanisms on return on assets, is specified below:

$$
\begin{aligned}
\mathbf{R O A}= & \beta \mathbf{0}+\beta \mathbf{1}(\mathbf{B S}) \mathbf{t}+\beta 2(\text { BI }) \mathbf{t}+\beta 3(\operatorname{LogER}) \mathbf{t} \\
& +\beta 4(\text { LogNER }) \mathbf{t}+\beta 5(\text { DO }) \mathbf{t}+\beta \mathbf{6}(\text { IO }) \mathbf{t} \\
& +\beta 7(\text { FO }) \mathbf{t}+\beta \mathbf{8}(\text { LogFS }) \mathbf{t}+\mu
\end{aligned}
$$

Where:

ROA = Return on assets

Bs $\quad=$ Board size.

$\mathrm{Bi} \quad=$ Board Independence.

Er = Executive remuneration.

Ner = Non-executive remuneration.

Do = Directors' ownership.

Io = Institutional ownership.

Fo $\quad=$ Foreign ownership.

Fs $\quad=$ Firm size (Log of total assets)

$\beta 0-\beta 8=$ Are the parameters

$\mu \quad=$ Stochastic factor/error term.

The study logged some of the variables to achieve the normality assumption of Ordinary Least Square (OLS) method.

\subsection{Analytical Techniques}

Three models were used in estimating the multiple regression model. They are the pooled regression model, fixed effects model and Random effects Model. The estimator goodness of fit was tested using the Hausman Test, adjusted multiple coefficient of determination (adjusted R2) and the F-statistics. In addition, Durbin Watson Statistics was used to detect the presence of auto colinearlity, while the estimated parameters were assessed using the coefficient and probability values.

\section{Analysis and Test of Hypotheses}

This section of the study presents the inferential statistics results, which was used for hypotheses testing. In investigating the effect of corporate governance mechanisms on financial performance of Insurance companies in Nigeria, this study employed three panel data models, that is, Pool regression model, fixed effects model, and Random effects model. The best estimator was determined by Hausman Test, Adjusted R-squared, F-statistics and its Probability value. 


\subsection{The Overall Econometric Model Discussion}

Considering the econometrics estimates presented in Table 1, the first estimate is of the pooled regression model. The pooled OLS estimator ignores the panel structure of the data and simply estimates the parameters and its usual standard errors are incorrect [86]. Thus, by pooling the data, the pooled regression model deny the heterogeneity or individuality that may exist among the companies in our study. In addition, the R-squared and the adjusted R-squared are very low, and the model is not statistically fit, since the F-statistics probability value is greater than 0.05 . Based on these facts, this study rejects the pooled regression model. The Second and Third estimators are fixed effects model and Random Effects Model respectively. The Fixed effects or LSDV Model allows for heterogeneity or individuality. While the Random effects model have a common mean value for the intercept.

\section{Hausman test}

In deciding whether to choose fixed effects model or random effects model, the Hausman test was conducted. In the Hausman Test presented above, the null hypothesis is that the preferred model is random effects, while the alternative hypothesis is that the fixed effects model is preferred [87].

Based on the probability of the hausman test presented in Table 2, the fixed effects model is preferred, since the probability is less than 0.05 . Meaning that the study rejects the null hypothesis of Hausman test, which states that random effects is preferred. And accept the alternative that fixed effects model is preferred. Therefore, based on the Hausman test, Adjusted R-squared and the Durbin Watson Statistics, the fixed effects model has been accepted as the best estimator of the effect of corporate governance mechanisms on the financial performance of Insurance companies in Nigeria.

Table 1. Econometrics estimates

\begin{tabular}{|c|c|c|c|}
\hline Variables & Pool Model & Fixed Effect Model++ & Random Effect Model \\
\hline BS & $-3.31657(-0.59697)$ & $-1.56149(-2.23797)^{* *}$ & $-1.30216(-2.30193)^{* *}$ \\
\hline BI & $-0.02472(-0.30855)$ & $0.24007(2.79342)^{* * *}$ & 0.12737 (1.69229)* \\
\hline LOGER & $2.13249(0.87833)$ & 4.00704 (1.09377) & $2.76752(1.00501)$ \\
\hline LOGNER & $-4.64100(-2.32257)^{* *}$ & $-5.87759(-2.69392)^{* * *}$ & $-4.44798(-2.44223)^{* *}$ \\
\hline DO & $-0.02308(-0.55585)$ & 0.14999 (1.17399) & $0.02064(0.33009)$ \\
\hline IO & $0.11911(2.55686)^{* *}$ & $0.32274(3.48110)^{* * *}$ & $0.17889(3.17818)^{* * *}$ \\
\hline FO & $-0.03942(-0.67221)$ & $-0.16659(-1.38915)$ & $-0.10043(-1.28821)$ \\
\hline LOGFS & $5.39863(1.66886)^{*}$ & $22.69593(2.76411)^{* * *}$ & $8.86126(1.90313)^{*}$ \\
\hline $\mathrm{C}$ & $-26.66204(-1.13677)$ & $-170.02(-2.82999)^{* * *}$ & $-59.61869(-1.81491)^{*}$ \\
\hline R-Squared & 0.14256 & 0.65847 & 0.21095 \\
\hline F-statistcis & 1.89129 & 5.14130 & 3.04109 \\
\hline Prob (F-statistics) & 0.07081 & 0.00000 & 0.00447 \\
\hline Durbin-Watson & 1.82899 & 2.52850 & 2.21417 \\
\hline
\end{tabular}

Source: Formatted by researcher from Eview result of regressions

$* * *, * *$ and $*$ represent $1 \%, 5 \%$, and $10 \%$ significance levels respectively.

Figures in brackets are t- statistics values. ++ = lead equation.

Table 2. Hausman test result

\begin{tabular}{|c|c|c|c|c|}
\hline Test Summary & & Chi-Sq. Statistic & Chi-Sq. d.f. & Prob. \\
\hline Cross-section random & & 17.507201 & 8 & 0.0252 \\
\hline \multicolumn{5}{|c|}{ Cross-section random effects test comparisons: } \\
\hline Variable & Fixed & Random & Var(Diff.) & Prob. \\
\hline BS & -1.561492 & -1.302158 & 0.166827 & 0.5255 \\
\hline BI & 0.24007 & 0.127386 & 0.00172 & 0.0066 \\
\hline LOGER & 4.007035 & 2.767516 & 5.838182 & 0.608 \\
\hline LOGNER & -5.877588 & -4.447982 & 1.443195 & 0.234 \\
\hline DO & 0.149994 & 0.020638 & 0.012415 & 0.2457 \\
\hline IO & 0.32274 & 0.178889 & 0.005427 & 0.0509 \\
\hline FO & -0.166589 & -0.100425 & 0.008304 & 0.4678 \\
\hline LOGFS & 22.695933 & 8.861257 & 45.739834 & 0.0408 \\
\hline
\end{tabular}

Source: Researcher's computation using Eview 8. 
Based on the fixed effects econometrics estimate presented in Table 1 above, the value of R-squared $\left(R^{2}\right)$ as 0.65847. Meaning that about $65.85 \%$ of the total variations observed in the dependent variable (Return on Assets), is explained by the independent variables. This implies that corporate governance mechanisms explained about $65.85 \%$ of the total variations observed in the financial performance of Insurance companies in Nigeria. However, the coefficient of multiple determination is biased, because of the inflation effect of adding more independent variables in the model, which consequently increase the value of R-squared. Thus, over-fitting the model and making it appears better and acceptable model because it has more terms (variables). This can be misleading, and can lead to type 1 or 2 error. In other to correct this, there is need to adjust the R-squared. The adjusted R-square is a modified version of $\mathrm{R}$-squared that have been adjusted for the number of predictors in the model. Unlike the R-squared, the adjusted R-squared increases only if the new variable improves the model more than would be expected by chance. Considering the result presented in Table 1, the adjusted R-squared of the fixed effects model is 0.53039. This implies that the unbiased explained proportion of the total variations observed in the dependent variable by the independent variables is about $53.04 \%$. This means that corporate governance mechanisms explained about $53.04 \%$ of the total variations observed in the financial performance of Insurance companies in Nigeria. Simply put, corporate governance mechanisms have about 53.04\% influence on financial performance of Insurance companies in Nigeria. However, to test if this influence is statistically significant, the F-statistics was considered.

The value of the F-statistics of the fixed effect model presented in the econometric estimates in Table 1 shows that the overall goodness of fit of the model is acceptable. It equally indicates that the influence of corporate governance mechanisms on financial performance as measured by R-squared is statistically significant, since the value of F-statistics is 5.1413 with a probability value of 0.0000 , which is less than 0.05 . Therefore, the study concludes that corporate governance mechanisms have a significant effect on financial performance of Insurance companies in Nigeria.

The Durbin-Watson Statistics of fixed effects model further supported the goodness of fit of the model and indicates that there is no evidence of autocorrelation in the model; since the value of Durbin-Watson Statistics 2.52850 is greater than the coefficient of multiple determination $\left(\mathrm{R}^{2}\right)$ [88]. Here, the study concludes that there is no evidence of autocorrelation and that the fixed effect model is fit for this study.

\subsection{The Specific Variables Discussion}

Here, the study assess the effect of the individual variables on the financial performance of insurance companies in Nigeria.

$H_{0}$ 1: Board size has no significant impact on the return on assets of insurance companies in Nigeria.

Considering the individual coefficients of the model variables, the fixed effects model estimate indicates that the Board Size (BS) coefficient is -1.56149. This implies that a unit increase in board size will lead to about 1.56149 proportional decrease in return on assets of Insurance companies in Nigeria. The minus sign indicates that the impact of board size on return on assets is negative. The t-test value of -2.23797 with probability value of 0.0283 indicates that the negative impact of board size on return on assets is statistically significant at $5 \%$, since the probability value is less than 0.05 . Hence, the study concludes that board size has negative and significant impact on return on assets. This study equally controls the possible influence coming from the firm size by including the log of total assets in the model. This result indicates that despite the positive influence of the firm size (in other words, despite the size of the firm), the board size of insurance companies' still exercise negative impact on return on assets. Therefore, there is a need to constitute a manageable board size to enhance the financial performance of the firm. This result is in line with the finding of Yermack [30], Eisenberg et al [31] and Vincent and Nicole [65].

The negative impact of board size on return on assets can be traced to the fact that boards with large number of directors may not make effective strategic plans and decisions because of many differences in ideas $[30,89]$. Lipton and Lorsch [28] observed that the average conduct in most boardrooms are dysfunctional, because directors rarely criticize the policies of top managers or hold candid discussion about corporate performance. Therefore, Lipton and Lorsch [28], Yermack [30], Eisenberg et al [31], Parker [89], and Vincent and Nicole [65] believed that these problems increase as the number of directors increases. When board size is large, individual directors will be less concerned about monitoring management, assuming that other directors are doing so. In addition, it should be noted that a director on the board of directors constitute cost to the business in terms of fees and remunerations. If this fees and remunerations paid to the directors are not matched with profit generating ideas, plans, efficient and effective monitoring of management and prevention of fraud, the financial performance of the business will decrease as the board size increases. Therefore, the study concludes that board size has significant negative impact on the return on assets of Insurance companies in Nigeria.

\section{$H_{0}$ 2: Board independence has no significant effect on the return on assets of Insurance companies in Nigeria.}

The coefficient of Board independence (0.240070) shows that a positive relationship exists between board independence and return on assets. Also implying that a unit increase in board independence will improve return on assets by about 0.24 . Simply put, an increase in the number of non-executive directors on the board of Insurance companies in Nigeria will lead to about 0.24 increase in their financial performance. The t-statistic value of 2.79342 and its probability value of 0.0067 indicates that the positive relationship between board independence and return on assets is statistically significant at $5 \%$, since the probability value is less than 0.05 . This result supports the monitoring model of the agency theory, which states that inclusion of more nonexecutive directors will enhance the monitoring of 
management and compel them to act in the best interest of the shareholders and other stakeholders. Thus, improving the financial performance of the firm. This finding is in line with the results of Anderson and Reeb, [36]; Mcknight and Mira, [70]; Vincent and Nicole, [65]; and Pinteris [71].

The positive relationship between board independence and return on assets of Insurance companies in Nigeria can be traced to the effective monitoring of management and strategic contributions to boardroom debate, which in turn improve the financial performance of the companies. According to Dalton and Dalton [90], boards with larger number of non-executive directors are more diverse in terms of experience, skills, nationality, and contribute more effectively to the performance of the company. In addition, information available to a firm through the nonexecutive directors can also affect the performance of the firm. Thus, the non-executive directors through their "watch dog" responsibility and wealth of experience from other sectors contribute to the financial performance of Insurance companies in Nigeria. Therefore, the study concludes that board independence has a significant positive effect on the return on assets of Insurance companies in Nigeria. Consequently, null hypothesis two, which states that board independence has no significant effect on the return on assets of Insurance companies in Nigeria, is hereby rejected.

$H_{0}$ 3: Executive directors' remuneration has no significant influence on the return on assets of insurance companies in Nigeria.

The fixed effects model in Table 1 equally shows that the coefficient of the log of executive directors' remuneration is 4.00704. This indicates that executive directors' remuneration positively affect return on assets of Insurance companies in Nigeria. Implying a unit increase in the log of executive directors' remuneration will lead to about 4.00704 increase in the return on assets of Insurance companies in Nigeria. However, the influence of executive directors' remuneration is not statistically significant at $5 \%$ since the t-statistics value is 1.09377 and its probability (0.2777) is less than 0.05 alpha level. This result is in line with the findings of Hristos et al [77] and Jegede [18].

The executive directors are involved in the activities of the firm daily, implementing strategic plans made by the board, ensuring that shareholders' wealth are maximized. They are equally burdened with the responsibility of meeting the interest of the stakeholders. However, the econometric result reveals that the motivation given to the executive directors in Insurance companies in Nigeria does not influence the financial performance of the companies significantly. Hence, this study accepts the null hypothesis and conclude that executive directors' remuneration has no significant positive influence on the return on assets of Nigerian insurance.

$H_{0}$ 4: Non-executive directors' remuneration has no significant impact on the return on assets of insurance companies in Nigeria.

The result presents the coefficient of log of non-executive directors' remuneration as -5.87759 . This reveals that non-executive directors' remuneration has negative impact on return on assets of Insurance companies in Nigeria. Implying that a unit increase in the log of non-executive directors' remuneration leads to about 5.88 decrease in return on assets of Insurance companies in Nigeria. The t-statistic of -2.6939 with probability value of 0.0088 indicates that the impact of non-executive directors' remuneration on return on assets of Insurance companies in Nigeria is statistically significant at $5 \%$.

The implication is that fees and allowances paid to non-executive directors' have negative impact on the return on assets of Insurance companies in Nigeria. This negative impact can be traced to the inability of the nonexecutive directors to effectively monitor the activities of executive directors', which despite the motivation given could not make significant impact on the return on assets of firms. The main responsibility of non-executive directors is to monitor the management to ensure they act in the best interest of shareholders. Thus, any failure in this duty could cause the remuneration paid to nonexecutive directors to influence return on assets negatively. Therefore, the study concludes that non-executive directors' remuneration has significant negative impact on return on assets of Insurance companies in Nigeria

\section{$H_{0}$ 5: Directors' ownership does not significantly affect the return on assets of insurance companies in Nigeria.}

From the fixed effects model, the coefficient of directors' ownership (DO) is 0.14999. This indicates that directors' ownership affects the return on assets of Insurance companies in Nigeria positively. Thus, an increase in the percent of directors' ownership will lead to about 0.14999 increase in the return on assets of Insurance companies in Nigeria. This basically means that a meaningful Director ownership will invariably bring about a better management monitoring which will in the long- run enhance firms' performance. This outcome further implies that firms with higher managerial stake tend to perform better than firms with a low level of directors' ownership. However, the t-statistics (1.17399) and its probability value (0.2443) shows that the positive effect of directors' ownership on the return on assets is not statistically significant at $5 \%$. This result conforms to the finding of Jensen and Murphy [91], Mehra [53], Chung and Pruitt [54].

According to Chung et al [54], directors with direct or indirect ownership in a company will not make the same decision with those that have no ownership. Other scholars such as Duc and Thuy [57] and Bhabra et al [56] in addition stress that directors with direct or indirect ownership in a firm under their watch will perform their monitoring and strategic responsibility effectively. This could be the reason for the positive effect of directors' ownership on return on assets. However, directors' ownership could not affect the return on assets significantly due to other factors, which may include the size of the board and the excessive remuneration of the non-executive directors as seen in the result of this study. In conclusion, directors' ownership does not significantly affect the return on asset of Insurance companies in Nigeria positively. Therefore, null hypotheses 5 , which states that directors' ownership does not significantly affect the return on assets of Insurance companies in Nigeria, is completely accepted. 


\section{$H_{0}$ 6: Institutional ownership does not significantly affect the return on assets of Insurance companies in Nigeria.}

The fixed effects model estimate indicates that the institutional ownership (IO) coefficient is 0.32274. This implies that a unit increase in institutional ownership will lead to about 0.32274 proportional increase in return on assets of Insurance companies in Nigeria. It equally indicates that the impact of institutional ownership on return on assets is positive. The t-test value of 3.48110 with probability value of 0.0009 indicates that the positive impact of institutional ownership on return on assets is statistically significant at $5 \%$, since the probability value is less than 0.05 . Hence, the study concludes that institutional ownership has positive and significant impact on return on assets. This result nevertheless corroborates the findings of Alfaraih et al [62], and Xu and Wang [47].

This finding supports the argument that firms with large institutional ownership will do better than those without. The argument was based on the fact that institutional ownership are in better position to effectively and efficiently monitor the management to ensure their wealth maximization. Therefore, this study concludes that institutional ownership significantly affects return on assets of insurance companies in Nigeria positively. Thus, reject the null hypothesis 6 , which states that Institutional ownership does not significantly affect the return on assets of Insurance companies in Nigeria.

\section{$H_{0}$ 7: Foreign ownership does not significantly affect the return on assets of insurance companies in Nigeria.}

Finally, from the fixed effects model, the result on the effect of foreign ownership on return on assets of Insurance companies in Nigeria further indicate that foreign ownership has negative affect on return on assets of Nigerian insurance company. This is evident in the coefficient of foreign ownership (-0.16659). It equally implies that an increase in percentage of foreign ownership will lead to a decrease in return on assets. Simply put, addition of foreign ownership will affect the return on assets negatively, that is, it reduces the financial performance of Insurance companies in Nigeria. This invariably suggests that the companies are yet to maximize the benefits of having foreign ownership. However, the t-statistics $(-1.389149)$ with its probability value of 0.1691 stipulate that the foreign ownership negative effect on the return on assets is not statistically significant at $5 \%$. In addition, it is important to note that only two out of twenty companies investigated had foreign ownership. The variable was included in the model because of the fixed effects model used for this study, which takes into account the individual difference of the companies. This result corroborates the findings of Millet-Reyes and Zhao [85] and Gurbuz and Aybars [63]. Therefore, the study concluded that foreign ownership has insignificant negative effect on return on assets of insurance companies in Nigeria.

\section{Recommendations}

Having come to the end of this study, the study offers the following recommendations based on the findings of this study:
Based on the significant negative impact of board size on the financial performance of Insurance companies in Nigeria, this study recommend that the board of directors be structure/restructure to a sizable number to enhance board effectiveness, which will in-turn improve firms' financial performance. Parker [89] noted that boards with sizable number will perform better than those with large number. Board of sizable number will make better strategic decisions, as there will be no much difference in ideas, strategies, and interest.

On the effect of board independence on financial performance of Insurance companies in Nigeria, the study recommends the appointment of more non-executive directors into the board of directors to enhance the independence of the board. It was found that board with high level of independence monitors the management effectively. Moreover, the non-executive directors brings with them wealth of experience, expertise, knowledge, and skills to improve the performance of the companies.

Shareholders and the non-executive directors should design a performance-based remuneration for executive directors to enhance the financial performance of the insurance companies.

Non-executive directors should improve in their monitoring of the executive's operations, protecting the assets of the firm, and holding executive directors and managers accountable to the firms' key stakeholders to ensure the survival, sustainability, and growth. Moreover, the various corporate governance codes, especially NAICOM, and insurance companies' shareholders should develop model to ensure that the non-executive directors perform their duties effectively and efficiently. The nonexecutive director's job should not be seen or treated as an honorary or political compensation.

Directors and institutions should be encouraged to invest more in the Insurance companies in Nigeria, as this will enhance the financial performance of the firms.

Literatures on corporate governance mechanisms are limited in Nigeria; the few available ones have some limitations in terms of sample size of firms used and number of corporate governance mechanisms used. The researcher therefore, recommends that more intensive study be conducted.

\section{References}

[1] Jensen, M.C., Murphy, K.J., \& Wruck, E.G. (2004). Remuneration: Where We've Been, How We Got to Here, What are the Problems, and How to Fix Them. Social Science Research Network. Available at www.ssrn.com.

[2] David, F., George, S.B. \& David, H. (2007). Corporate Boards and Company Performance: Review of Research in Light of Recent Reforms. Journal Compilation, Vol. 15, no. 5.

[3] Duztas, S. (2008). Corporate Governance: the Effects of Board Characteristics, Information Technology Maturity and Transparency on Company Performance. Yeditepe University Graduate Institute of Social Science.

[4] Durisin, B., \& Puzone, F. (2009). Maturation of Corporate Governance Research, 1993-2007: An Assessment. Corporate Governance: An International Review, Vol. 17, no. 3, pp. 266-91.

[5] Filatotchev, I (2009). Taking Stock of Corporate Governance Research While Looking to the Future'. Corporate Governance: An International Review, Vol. 17, no. 3, pp. 257-65.

[6] Belkhir, M. (2005). Board Structure, Ownership Structure, and Firm Performance: Evidence from Banking. Laboratorie d' Economie d' Orleans, University of Orleans. France. 
[7] Ogbechie, C. I. (2012). Key determinants of Effective Boards of Directors-Evidence from Nigeria. Brunel Business School. Brunel University, London.

[8] Permanent Subcommittee on Investigation (2002). The Role of the Board of Directors in Enron's Collapse. United State Government Printing office Washington.

[9] Laufer, W. S. (2006). Illusions of Compliance and Governance. Corporate Governance, 6(3), 239-249.

[10] Vaughn, M., \& Verstegen Ryan, L. J. (2006). Corporate Governance in South Africa: a bellwether for the continent? Corporate Governance: An International Review, 504-512.

[11] Abdullah, S.A. (2004). Board Composition, CEO Duality and Performance among Malaysian Listed Companies. Corporate governance, Vol. 4 (4): 47-61.

[12] Richard, P., \& Bill, N. (2006). Corporate Finance and Investment: Decisions and Strategies. Financial time publication.

[13] Garba, T. \& Abubakar, B.A. (2014). Corporate Board Diversity and Financial Performance of Insurance Companies in Nigeria: An Application of Panel Data Approach. Asian Economic and Financial Review, Vol. 4, no. 2, pp. 257-277.

[14] McGee, R. W. (2010). Working Paper: Corporate Governance in Transition and Developing Economies: A Case Study of South Africa. Retrieved from http://papers.ssrn.com/sol3/papers.cfm?abstract_id=1665985.

[15] Kajola S.O (2008). Corporate Governance and Firm Performance: the Case of Nigerian Listed Firm. European journal of economics, finance and administrative science, ISSN 1450-2275 issue 14 (2008)

[16] Babatunde, M.A., \& Olaniran, O. (2009). The Effect of Internal and External Mechanism on Governance and Performance of Corporate Firms in Nigeria. Corporate ownership and control, Vol. 7, issue 2.

[17] Iwu-Egwuonwu, R.C. (2010). Some Empirical Literatures Evidence on the Effects of Independent Directors on Firm Performance. Journal of economics and International finance, Vol. 2(9), pp. 190-198.

[18] Jegede, C.A. (2012). Executive Compensation Structure, Ownership and Firm Performance Nexus: An Empirical Analysis. European Journal of Humanities and Social Sciences, Vol. 17(1).

[19] Ajala, O.A., Amuda, T., \& Arulogun, L. (2012). Evaluating the effects of corporate governance on the performance of Nigeria Banking Sectors. Review of contemporary business research, Vol. $1(1)$, pp 32-42.

[20] Ioraver, N.T., \& Wilson, E.H. (2013). Corporate Governance, Ownership structure and firm performance in Nigeria. Research Journal of Finance and Accounting, vol. 4, no. 5, ISSN 2222-2847.

[21] Junaidu, M.K., \& Sani, K.S. (2014). Executive Compensation and Financial Performance of listed Banks in Nigeria: An Empirical Analysis. Research journali's Journal of Accounting, Vol. 2(3).

[22] Sanda, A.U, Mikailu, A.S., \& T, Garba, (2005). Corporate Governance Mechanisms and Firm Financial Performance in Nigeria. African Economic Research Consortium (AERC) Research Paper 149, Nairobi.

[23] Roche, J. (2005). Corporate Governance in Asia. Oxon: Routledge.

[24] Armstrong, A., \& Sweeney, M. (2002). Corporate Governance Disclosure: Demonstrating Corporate Social Responsibility through Social Reporting. New Academy Review, Vol. 1, no. 2, pp. 51-69.

[25] Bain, N., \& Band, D. (1996). Winning Ways through Corporate Governance, Macmillan Press Ltd, London.

[26] Chowdary, N.V. (2003). Corporate Governance in Emerging Markets Volume 1. Corporate Governance, ICFAI Press Hyderabad.

[27] Sanda, A.U, A.S, Mikailu \& T, Garba, (2008). Board Independence and Firm Financial Performance: Evidence from Nigeria. A paper submitted to the Centre for the Study of African Economies (CSAE), for presentation at the CSAE conference 2008, St Catherine's college, University of oxford, 16 march, 2008.

[28] Lipton, M., \& Lorsch, J.W. (1992). A Modest Proposal for Improved Corporate Governance. Business Lawyer, Vol. 48(1), pp. 59-77.

[29] O’Reilly III, C. A., Caldwell, D. F., \& Barnett, W. P. (1989). Work Group Demography, Social Integration, and Turnover. Administrative Science Quarterly, 34(1), 21-37.

[30] Yermack, D. (1996). Higher Market Valuation of Companies with a Small Board of Directors. Journal of Financial Economics, Vol 40, pp 185-211.
[31] Eisenberg T., Sundgren S., \& Wells, M. (1998). Larger Board Size and Decreasing Firm Value in Small Firms. Journal of Financial Economics, Vol 48, pp 35-54.

[32] Jensen, M. C. (1993). The Modern Industrial Revolution, Exit and the Failure of Internal Control Systems. Journal of Finance, 48(3), 831-880.

[33] Pfeffer, J. (1972). Size and Composition of Corporate Boards of directors: The Organization and its Environment. Administrative Science Quarterly 17: 218-229.

[34] Hermalin, B. E., \& Weisbach, M. S. (1988). The Determinants of Board Composition. RAND Journal of Economics, 19(4), 589-606.

[35] Klein, A. (1998). Firm Performance and Board Committee Structure. Journal of Law and Economics, 41(1), 275-303.

[36] Adams, R. B., \& Mehran, H. (2003). Is Corporate Governance Different for Bank Holding Companies? Economic Policy Review - Federal Reserve Bank of New York, 9(1), 123-142.

[37] Anderson, R., Mansi S. \& D, Reeb (2004). Board characteristics, Accounting Report Integrity and the Cost of Debt. Journal of Accounting and Economics, Vol. 37, pp. 315-342.

[38] Coles, J. L., Daniel, N. D., \& Naveen, L. (2008). Boards: Does One Size Fit All? Journal of Financial Economics, 87(2), 329-356.

[39] Jensen, M., \& Meckling, W. (1976). Theory of the Firm: Managerial Behaviour, Agency Costs and Ownership Structure. Journal of Financial Economics, 3: 305-360.

[40] Mohammad, T., Abdullah, S., \& Masuod, S.M. (2009). Corporate Governance and Directors' Remuneration in selected ASEAN Countries. The Journal of applied business research, Vol. 25(2).

[41] Greenbury, R. (1995). Report on Directors' Remuneration. London: Gee Publishing.

[42] Harnizam B.N. (2008). Directors' Remuneration and Firms' Performance Among Malaysia's Government-linked Company (GLCs) and Non-GLCs. Dissertation submitted in partial fulfilment of the requirements for the degree of master of accountancy. Universiti Teknologi Mara.

[43] Miyienda, B., Oriere, C.O., \& Miyogo, J. (2013). The Relationship between Directors' Remuneration and Performance of Firms' listed in the Nairobi securities exchange. The International Journal of Social Sciences, Vol. 15(1). ISSN 2305-4557. www.tijoss.com.

[44] Kevin, A., \& Leigh Drake (2003). Executive Remuneration and Firm Performance: Evidence from a Panel of Mutual Organisations. No 03/13, Discussion Papers in Economics, Department of Economics, University of Leicester, http://EconPapers.repec.org/RePEc:lec:leecon:03/13.

[45] Bushman, R., \& Smith, A. (2001). Financial Accounting Information And Corporate Governance. Journal of Accounting and Economics, Vol. 32, no. 1-3, pp. 237-333.

[46] Shleifer, A., \& Vishny, R. W. (1997). A Survey of Corporate Governance. Journal of Finance, 52(2), 737-783.

[47] Xu, X. and Wang, Y. (1997). Ownership Structure and Corporate Governance in Chinese Stock Companies. China Economics Review, 10, 75-94.

[48] Houda, A., Mohammed, H., \& Mahammad, B.M. (2011) Ownership Structure, Corporate Governance and Bank Performance: Evidence from GCC Countries. Corporate Ownership and Control, Vol. 8, no. 4, pp. 365-372.

[49] Zeitu, R., \& Tian, G.G. (2007). Capital Structure and Corporate Performance: Evidence from Jordan. Australasian Accounting, Business and Financial Journal, Vol. 1(4).

[50] Shleifer, A., \& Vishny, R. W. (1986). Large Shareholders and Corporate control. Journal of Political Economy, 94(3), 461-488.

[51] Fama, E. F., \& Jensen, M. C. (1983). Separation of Ownership and Control. Journal of Law and Economics, 26, 301-325.

[52] Brickley, J. A., Lease, D., \& Smith, R. C. W. (1988). Ownership Structure and Voting on Anti-Takeover Amendments. Journal of Financial Economics, 20(1-2), 267-291.

[53] Mehran, H. (1995). Executive Compensation Structure, Ownership, and Firm Performance. Journal of Financial Economics, 38 (2).

[54] Chung, K. H. and S. W. Pruitt (1996), Executive Ownership, Corporate Value and Executive Compensation: A Unifying Framework. Journal of Banking and Finance, 20, 1135-1159.

[55] Gedajlovic, E., R \& Shapiro, D. M. (1998). Management and Ownership Effects: Evidence from Five Countries. Strategic Management Journal, 19(6), 533-553. 
[56] Bhabra, G. S., Ferris, P. S., \& Seri, N. (2003). Corporate Governance in Singapore: The Impact of Director Equity Ownership. Advance in Financial Economics, Vol. 8, 29-46.

[57] Duc, V. \& Thuy, P. (2013). Corporate Governance and Firm Performance: Empirical Evidence from Vietnam. Journal of corporate governance, Vol. 4, no. 3.

[58] Aljifri, K., \& Moustafe, M. (2007). The Impact of Corporate Governance Mechanisms on the Performance of UAE Firms: An Empirical Analysis. Journal of Economic and Administrative Sciences, Vol. 23(2), 72-94.

[59] Al-Shiab, M., \& Abu-Tapanjeh, A. (2005). Ownership Structure and Firm Performance: The case of Jordan. Journal of Business Administration, Vol. 1 (2), 1-27.

[60] Denis, D. J. \& Denis, D. K. (1994). Majority Owner-Managers and Organizational Efficiency. Journal of Corporate Finance, Vol. 1, pp. 91-118.

[61] Omran, M., Bolbol, A., \& Fatheldin, A. (2008). Corporate Governance and Firm Performance in Arab Equity Markets: Does Ownership Concentration Matter? International Review of Law and Economics, 28(1), 32-45.

[62] Alfaraih, M., Alanezi, F., \& Almujamed, H. (2012). The Influence of Institutional and Government Ownership on Firm Performance: Evidence from Kuwait. International Business Research, Vol. 5, no. 10, pp.192-200.

[63] Gurbuz, A. O., \& Aybars, A. (2010). The Impact of Foreign Ownership on Firm Performance, Evidence from an Emerging Market: Turkey. American Journal of Economics and Business Administration, 2(4), 350-359.

[64] Pandey I.M. (2010). Financial Management. $10^{\text {th }}$ edition, Vikas Publishing House PVT LTD, Jangpura, New Delhi.

[65] Vincent O. \& Nicole C. (2010). The Relationship between Firm Performance and Board Characteristics in Ireland. European management journal, Vol. 28, pp 387-399.

[66] Masood, F.C. (2011). Corporate Governance and Firm Performance. International conference on sociality and economic development, (IDEDR) Vol. 10 (2011), LACSIT press, Singapore.

[67] Uadiale, M. (2010). The Impact of Board Structure on Corporate Financial Performance in Nigeria. International Journal of Business and Management, 5(10), 155-166.

[68] Amran, N.A. (2011). Corporate Governance Mechanisms and Company Performance: Evidence from Malaysian Companies. International Review of Business Research Papers, Vol. 7(6): 101-114.

[69] Al-Manaseer, M.F. Al-Hindawi, R.M., Al-Dahiyat, M.A., \& Sartawi, I.I. (2012). The Impact of Corporate Governance on the Performance of Jordanian Banks. European. Journal of Scientific Research, Vol. 67(3): 349-359.

[70] McKnight P.J. \& Mira S. (2003). Corporate Governance Mechanisms, Agency Costs and Firm Performance in UK Firms. http://ssrn.com/abstract $=460300$.

[71] Pinteris, G. (2002). Ownership Structure, Board Characteristics and Performance of Argentine Banks. Mimeo, Department of Economics, University of Ilinois.

[72] Giorannini, R. (2010). Corporate Governance, Family Ownership and Performance. Journal of management and governance, Vol 14, pp 145-166.

[73] Hermalin, B.E., \& Weisbach, M.S. (1991). The Effects of Board Composition and Direct Incentives on Firm Performance. Financial Management Journal, Vol. 20, no 4, pp. 101-112.
[74] Jackling, B., \& Johl, S. (2009). Board Structure and Firm Performance: Evidence from India's Top Companies. Corporate Governance: An International Review, Vol. 17, no 4, pp. $492-509$

[75] De Andres P., Azofra, V. \& Lopez, F. (2005). Corporate Boards in OECD Countries: Size, Composition, Functioning and Effectiveness. Corporate Governance, Vol. 13, no.2, pp. 197-210.

[76] Metrick, A., \& Ishil (2002). Firm-level Corporate Governance. Paper Presented at Global Corporate Governance Forum Research Network meeting, Washington D.C April.

[77] Hristos, D., Saeed, A., \& Janto A. (2006). Directors' Remuneration and Performance in Australian Banking. School of Accounting, Economics, and Finance working paper, Deakin University.

[78] Ani, W.U., Ilo, J.V.C., Timothy, A.A., \& Eneje, B.C. (2014). The Impact of Directors' Equity Ownership on Bank Profitability in Nigeria: The triumph of quality over quantity. Advance Business Management and Entrepreneurship, Vol. 2 (001), pp. 001-010.

[79] Gugong, B.K., Arugu, L.O. \& Dandago, K.I. (2014). The Impact of Ownership Structure on the Financial Performance of listed Insurance Firms in Nigeria. International Journal of Academic Research in Accounting, Finance and Management Sciences, Vol. 4, no. 1, pp. 409-416.

[80] Tsegba, I.N., \& Herbert, W.E. (2003). Corporate Governance, Ownership Structure and Firm Performance in Nigeria. Research Journal of Finance and Accounting. Vol. 4, no. 5, ISSN: 22222847.

[81] Uwuigbe, U., \& Olusanmi, O. (2012). An Empirical Examination of the Relationship between Ownership Structure and the Performance of Firms in Nigeria. International Business Research, Vol. 5, no. 1.

[82] Mihai, I.O., \& Mihai, C. (2014). The Impact of Foreign Ownership on the Performance of Romanians listed Manufacturing Companies. The International Journal of Management Science and Information Technology. Vol. 2. Pp. 106-122.

[83] Leung, S., \& Horwitz, B. (2010). Corporate governance and firm value during a financial crisis. Review of Quantitative Finance and Accounting, (34), 459-481.

[84] Bhagat, S., \& Bolton, B. (2009). Corporate Governance and Firm Performance: Recent Evidence. International Journal of Accounting, Vol. 8(3). 1-57.

[85] Millet-Reyes, B., \& Zhao, R. (2010). A Comparison between Onetier and Two-tier Board Structures in France. Journal of International Financial Management and Accounting, 21(3), 279-310.

[86] Kurt, S. (2015). Short Guides to Micro Econometrics. Universitat Basel.

[87] Greene, W.H. (2008). Econometric analysis. 6th ed. Prentice Hall, Upper Saddle River, N.J.

[88] Gujarati, D. (2004). Basic Econometrics. New Delhi: Tata McGraw-Hill Publishing Limited.

[89] Parker H. (2006). Governing the Corporation, Business the Ultimate, A \& B Black Publishers Ltd, 2006.

[90] Dalton, C.M. \& Dalton, D.R. (2005). Board of Directors: Utilizing Empirical Evidence in Developing Practical Prescriptions. British Journal of Management, Vol. 16, Issue S1, 91-97

[91] Jensen, M., \& Murphy, K. (1990). Performance Pay and Top-management Incentives. Journal of Political Economy, 98(2), 225-264. 